\title{
Will agriculture beat the odds against Covid-19? The Covid-19 outbreak and its effect on agricultural supply in Turkey
}

\author{
Ismail Bulent Gurbuz*, Gulay Ozkan*
}

DOI: $10.30682 / \mathrm{nm} 2102 \mathrm{~b}$

JEL codes: D1, I18, Q11, Q18

\begin{abstract}
The new coronavirus (Covid-19), which spread almost the entire world, adversely affected many sectors, both internationally and locally. Households' panic purchase has rocketed the demand for some food items in the early days. Besides, food safety concerns have increased. This research aimed to uncover how the public perceived the impact of Covid-19 on the agriculture and food sector. The online survey was conducted, and the data from 428 participants were analysed using the SPSS (v.23) program. The third of respondents (30.8\%) believed the outbreak would last between six months to one year, during which time food shortages will occur (32.5\%). While $27.4 \%$ of the respondents reported that they stockpiled food, $44.8 \%$ reported that if the outbreak continued, they would stock up on food. Participants were concerned that if planting cannot be done, food shortages will occur (74.6\%), basic foodstuffs cannot be produced (67.8\%), food imports (69.4\%) and exports (74.6\%) will be adversely affected by the outbreak. The research found that if farming disturbed, food prices would increase (82.3\%) and the government should include agriculture-supporting measures (85\%) in its economic measures.
\end{abstract}

Keywords: Coronavirus, Outbreak, Consumer, Food safety, Agricultural policy, Trade restrictions.

\section{Introduction}

The coronavirus (Covid-19) broke out at a time when the world economy was very fragile. The novel Covid-19 outbreak has had unprecedented effects on the world economy in the history of capitalism. For example, the crises of 1873-1888, 1929-1933 and 2007-2008 were mainly centred on the developed countries. During the 2007-2008 crises, developing countries continued to grow, offering relatively protected harbour for capitals fleeing the crisis. This time, developing countries have also been unable to escape the deadly effect of Covid-19, nor the devastating economic con- sequences it causes. The adverse impacts of the 1930s depression and the 2007-2008 crises took about 2-3 years to emerge in the stock markets, production and unemployment. However, the effects of Covid-19 manifested itself within 1-2 weeks (Yildizoglu, 2020).

In the early days of the outbreak, the focus was purely on economic indicators, and the risk of a food crisis was overlooked. Now that risk has begun to be on the top the agenda. There was a significant increase in food demand at the beginning of the Covid-19 pandemic for household consumption. In contrast, the closure of restaurants, cafes, eateries, and school dining halls re-

\footnotetext{
* Department of Agricultural Economics, Faculty of Agriculture, Bursa Uludag University, Nilufer/Bursa, Turkey. Corresponding author: bulent@uludag.edu.tr
} 
duced demand for fruit vegetables, meat and fish for commercial consumption, and affected the producer and supplier. The agriculture and aquaculture sectors are particularly affected by the disruption of tourism activities. The quarantine conditions have led consumers turned to products such as legumes and flour, which they can store for a long time at home. Recommendations from nutritionists on keeping the immune system healthy during the outbreak also increased the demand for legumes.

A statement from the United Nations Food and Agriculture Organisation (FAO) said there was enough food for all in the world, and global grain stocks were at sufficient levels for 2020 (Yuruk, 2020). The sudden rise in demand for food products increased prices in international markets. Some countries resorted to measures such as imposing export bans on certain agricultural products, tightening customs enforcement and nullification of import tariffs to ensure adequacy and price stability in the domestic market. FAO also warned that the above applications added with possible problems in the logistics of agricultural workers could lead to food supply shortages in some parts of the world within a few weeks (Ozdemir, 2020).

Agricultural goods produced need to be transported across borders. As countries closed their borders to all kinds of transportation, moving goods were stopped either, and supply chains started to break. These chains provide both the food needed to feed the people of the developed country and the income that funds the livelihood of the country from which the workers come through seasonal labour movements. Supermarkets all over the world, especially in the United States (US) and Europe, can offer suitable food products to their citizens owing to the products brought from developing countries. The break-up of supply chains caused the clearing of supermarket shelves and increased the prices of products on the shelves. Thus, food consumption of the low-income part of the population adversely affected. On the other side, unsold products were left in the hands of the farmers' because breaking the supply chain. Farmers were forced to sell these products at lower prices, resulting in lower-income and financial hardship (Schrotenboer, 2020).

Russia, the world's largest grain exporter, imposed restrictions on the export of grains such as barley and wheat, while Vietnam and Cambodia suspended their exports of rice, maise, lentils for some time. Such practices raise concerns in relatively emerging countries, such as Egypt, Algeria and Sub-Saharan Africa, which import food to a large extent, both in terms of the price increase and supply problems (Yildizoglu, 2020).

Agriculture and animal husbandry, especially fresh vegetables, fruit production and yields rely on migratory and seasonal labour movement between countries. Disruptions in food supply chains are expected in April and May. Agricultural enterprises in Europe and the United States presumably face labour shortage because of measures that prevent the free movement of seasonal agricultural workers. The fact that the majority of agricultural workers are of advanced age, poor working conditions and lack of hygiene measures lead the farmers to avoid working during the pandemic, therefore causes disruptions in farms and food establishments that handle the vast majority of agricultural products.

The shortage of fertiliser, veterinary medicines and other inputs can affect agricultural production. Measures to guarantee acceptable health standards in food factories could slow production. Many countries impose higher controls on cargo ships at risk of endangering shipping vessels (Yuruk, 2020).

\section{Turkey and the effects of outbreak}

The first case of Covid-19 was detected on March 10 in Turkey. The first virus-related death in the country occurred on March 15, 2020. Turkey ranks the 7 th country with the most cases, while the death toll rose to 12 th among 185 countries. As in other countries of the world, the outbreak has caused radical decisions to be made in Turkey, which has important implications and consequences on social, economic, political, administrative and legal issues. Restaurant, eateries, patisserie were allowed to serve only as home delivery or take away. Cafes, shopping centres and picnic areas 
were closed to visitors. The government first imposed a curfew on people aged 65 and older in order to reduce the spread of the outbreak on March 21. Later, this restriction expanded to include children and young people aged 20 and under. Overseas flights were reduced first, completely stopped on March 27. Inter-city transportation was subjected to the governor's permit in 30 municipalities and Zonguldak where lung diseases were common. The population of these provinces corresponds to $75 \%$ of the country's population. On April 11-12, 2020, a wide-ranging curfew was declared, and this implemented every coming weekend.

Agricultural experts in Turkey have been warning about problems that may occur and the measures to be taken for the farming sector since the pandemic broke out. From the first days of the pandemic, people rushed to markets and grocery stores. This behaviour was commonly witnessed in situations of panic. They stocked up on food supplies because people had to be isolated in their homes for an uncertain period. The 2020 Wheat Report of the National Grain Council emphasised that the agriculture and food sector will be most affected by the pandemic. The report underlined that there is an upward trend in food prices in the world due to the restriction decisions producer countries take on exports to meet the needs of their domestic markets and to prevent price increases that may occur due to the exportation of those products. Already Russia, Kazakhstan and Romania placed export bans on products such as wheat and sunflower. Turkey placed restrictions on the export of onions, potatoes and lemons. However, as of now, the products that are banned from export do not see a price decrease in the domestic market. Instead, the price increase is observed due to the panic purchases of the public. Exporting these products would have both increased the prices and make their supply more difficult.

Turkey, a country that is generally self-sufficient in fruits and vegetables, may face severe problems in the future, especially in cereals, forage crops and oil plants. It is production season right now. Sowing, planting, spraying is being done with limitations. Harvest of some fruits will begin in June. There are problems such as the inability to plant seedlings ordered in various parts of the country. If the current production season is missed, there will not be a further harvest for a year. Imports and scarcity cannot compensate food demand and scarcity could be on the agenda. The curfew disrupts the supply chain from producer to consumer in Turkey; therefore, the products that are harvested must be delivered to the public (Yildirim, 2020).

The risk that coronavirus posed negatively affected farmers over the age of 65 . The average age of 2.1 million farmers registered in the Farmer Registration System (FRS) in Turkey is 55. According to the data of the Turkish Statistical Institute, $65.5 \%$ of those over the age of 65 are employed in agriculture. In other words, $65.5 \%$ of the working-age population in Turkey is in the agricultural sector. This ratio is $63 \%$ in men and $72 \%$ in women (Bal, 2020). In the early days of the pandemic, farmers could not go to the fields, vineyards and groves because citizens of this age group were forbidden to go out across the country. However, they were soon exempted from the curfew to prevent food production disruptions providing that they take necessary precautions (Ozkok, 2020).

Seasonal agricultural labour is employed in sowing, planting and harvesting. For example, tea collection in Rize was carried out with workers from Georgia. They will not be coming in 2020 spring and summer this due to travel restrictions. Farmers attempted to counterbalance this shortage with the domestic workers coming from a wide array of cities for tea collection, which was done in late April and early May. However, domestic travel has been restricted. There will be delays in tea collection, labour costs will increase, and the earnings of the producer will decrease. About one million seasonal and temporary agricultural workers often work in deplorable housing conditions, and without health insurance, the majority of them are from Eastern, Southeastern Anatolia regions and Syrians. The Ministry of Interior and the Ministry of Agriculture and Forestry issued two separate circulars. After these circulars, the first steps were taken for seasonal agricultural workers to work in production and harvest. Producers avoid hiring seasonal workers 
for harvest because they fear seasonal workers will bring viruses, and there is a danger that crops may remain in the field.

Covid-19 has been a hot topic in the past few weeks since the virus spread to Europe and began causing high casualties, although it has been on the world agenda since the final days of 2019. Research on Covid-19 is still very recent, and these are being carried out in the medical and health sciences. A study examining the effects of Covid-19 in terms of agriculture and food sector has not yet been found. Therefore, it is hoped that this research will be one of the first studies and will fill the gap in this field.

The primary purpose of this research is to examine how the public perceives the impact of Covid-19 on agriculture food supply. Turkey, the virus in terms of exposure and the measures taken, have experienced similar problems with Europe and the rest of the world. Since Turkey's economy is largely based on agricultural production, its high population and proximity to the most affected countries, we believe that the results of the research from Turkey will serve as an example for similar research and guide future research to make general assumptions.

\section{Methodology}

\subsection{The universe and the sampling}

This research is designed to include entire Turkey. Since there is no established literature in the scope of the study, official institutions' websites, current journal and newspaper articles, TV interviews and comments of experts in the field were scanned to evaluate the problems caused by the epidemic. The compiled comments were appraised by academicians who are experts in the field of agriculture, and a pool of questions was created. The preliminary survey was tested with ten people. Some of the statements have been rephrased to make them easier to understand, and the survey has been finalised. At the time the survey was prepared, there was a widespread curfew restriction in Turkey. Professional groups with the possibility of working outside the office were encouraged to work from home. Almost all the white collars were subjected to home isola- tion. Only blue-collar workers were allowed to work in a few sectors. In these circumstances, it was not possible to meet the participants faceto-face and the survey was conducted online. A total of 428 responses were collected.

\subsection{Data collection}

The survey consists of 4 parts and 42 questions. In the first part, participants were asked six questions about their socio-demographic characteristics. In the second part, five multiple-choice questions were asked about how the participants perceive coronavirus. Besides, there were three additional a 5 point Likert type questions: 'in your opinion how fatal is the coronavirus' $(1=$ not at all fatal, $5=$ extremely fatal), and the question of 'in your opinion what is the probability of getting coronavirus' ( 1 = extremely unlikely, 5 = extremely likely). The final part, 15 questions were asked, measuring participants' views on how coronavirus will affect the food and agriculture sector. All of part there and four questions were prepared in 5 point Likert-type ( $5=$ strongly agree, $1=$ strongly disagree). Exemption applied to two questions, which were coded as $1=$ none of my shopping, $5=$ all of my shopping.

\subsection{Data analysis}

The data obtained from the survey forms were processed into the SPSS 23.0 package program. We performed the Cronbach's alpha test to measure the internal consistency coefficient of the items included in the questionnaire. We calculated Cronbach alpha as $\alpha=$ 0.84 ; therefore, our survey meets the reliability criterion. Additionally, the mean, standard deviation kurtosis and skewness values of the variables were calculated. Next, we tested the normality assumption using a Shapiro-Wilk test. The analysis showed that $[\mathrm{D}(428)=0.956$ $p<0.001]$ the data does not provide normal distribution. Therefore, we further used the skewness and kurtosis values and found that skewness of $-0.926(\mathrm{SE}=0.118)$ and kurtosis of $1.879(\mathrm{SE}=0.235)$. George and Mallery (2010) suggest that the data show the normal 
distribution in cases where the corresponding variables have kurtosis and distortion values are in the range of \pm 2 .

\section{Findings}

The socio-demographic characteristics of the participants, such as gender, age, educational level, professional status, number of individuals in the family and the city in which they live, are summarised in Table 1.

\section{Results and Discussion}

The primary purpose of this study was to demonstrate people's views on how agriculture and therefore, the food sector would be affected by the coronavirus pandemic. The agricultural sector is already one of the most problematic sectors. The problems faced by the agricultural sector (including animal husbandry) in both developed and developing countries are often the subject of intensive research. The current pandemic once again highlighted the various problems of the agricultural sector. Still, those problems were mostly addressed by conflicting but mostly temporary policies, rather than permanently resolved. Since the emergence of the outbreak, people have been bombarded with data through traditional and social media. There has been heaps of contrasting information from a wide array of sources about coronavirus, its origin, symptoms, contagiousness, lethality so on. This part of the study aimed to understand how the participants perceived the issues involved, not whether their knowledge of the coronavirus was correct.

Table 1 - Demographic characteristics of the participants $(\mathrm{N}=428)$.

\begin{tabular}{|l|l|c|c|}
\hline Demographics & Categories & Frequency & Per cent \\
\hline Sex & Female & 265 & 61,9 \\
& Male & 163 & 38,1 \\
\hline Age & $20-29$ & 92 & 21,5 \\
& $30-39$ & 80 & 18,7 \\
& $40-49$ & 107 & 25,0 \\
& $50-64$ & 131 & 30,6 \\
& $65+$ & 18 & 4,2 \\
\hline Educational attainment & Primary school & 4 &, 9 \\
& Secondary school & 6 & 1,4 \\
& High school & 63 & 14,7 \\
& University Graduate & 355 & 82,9 \\
& Primary school & 4 & 0,9 \\
\hline Professional Status & Housewife & 26 & 6,1 \\
& Civil servant & 105 & 24,5 \\
& Trained workforce * & 111 & 25,9 \\
& Labourer** & 23 & 5,4 \\
& Craftsman/shop keeper & 163 & 34,8 \\
& Retiree & 79 & 18,5 \\
& Student & 46 & 10,7 \\
\hline How many people are in your & 1 & 18 & 4,2 \\
family, including you? & 2 & 139 & 18,2 \\
& 3 & 137 & 32,5 \\
& 4 & 56 & 32,0 \\
& 4 & & 13,1 \\
\hline
\end{tabular}

Notes: *private sector / white collar; **private sector / blue collar. 


\subsection{Effects of Covid-19 on farmers and agricultural production}

Agricultural activities such as sowing, planting, maintenance and harvesting have to be performed required at a specific time. Under normal conditions, Turkey is self-sufficient in the production of cereals, vegetables and fruits. Nevertheless, agricultural production activities are adversely affected as a result of the measures taken due to the coronavirus outbreak in the provinces where most of the country's fresh fruit and vegetable needs are met. March and April, when the outbreak was first seen in Turkey (and in Europe), are the time of planting industrial plants. Fertiliser application that should be done at the beginning of April could not be made adequately. Hoeing, weed cleaning had to be done; these could not be undertaken either (Yildizalp Ozmen, 2020a). Therefore, diseases and damage caused by wild animals increased in production areas. Strawberry harvest was left in the field due to farmer' inability to cover the cost of production (Is1k, 2020). Many farmers similarly ploughed the fields without picking up the fruit and vegetables. Black Sea provinces will need to collect tea and nuts in early May. Wheat harvest is expected to begin in early June. Temporary-seasonal workers mostly tackle fertilisation, spraying and harvesting. The inability of the already elderly farmer to go to the land and the absence of seasonal workers in the field increases the possibility of food shortage (Yildizalp Ozmen, 2020b). Seeds import cannot be made because of the Covid-19 outbreak, for the reasons that countries impose restrictions on seed sales (Calkaya, 2020). The exchange rate fluctuations occurred during the outbreak; exorbitant increases in fertiliser, diesel and agrochemicals negatively affected farmers and harvests (Batuk, 2020).

On the one hand, while the above mentioned problems were experienced in production, both domestic sales and export increased. This raises the issue of being able to compensate food stocks that are already at a minimum level for the coming season (Aslanhan, 2020). The Ministry of Agriculture and Forestry and the Turkish Grain Board (TGB) state that there is sufficient wheat stock (Yildirim, 2020). The UN Food and Agriculture Organisation (FAO) ensured that there is enough food for everyone in the world and global grain stocks are at a positive level for 2020 . However, as the virus spread, cases increased, and measures tightened in the forthcoming days, FAO pointed out that various problems might occur in the global food system. Besides, FAO noted that developing countries and countries with high food imports might face a food crisis (Tan, 2020; Ozdemir, 2020; Yuruk, 2020).

The problems detailed above and the concerns caused by them were reflected in the participants' answers. Two-thirds of respondents $(M=$ $4.25, S D=1.01)$ believe that outbreak measures will hamper agricultural production, and this will cause shortages in the food supply. An even greater majority is concerned that farmers are unable to perform their routine tasks due to the outbreak, and therefore farmers, who already find it challenging to make ends meet, can suffer more significant economic losses $(M=4.09$, $S D=0.91)$. A substantial amount the respondents was concerned that food might not be produced enough to meet their basic food needs $(M=3.96$, $S D=1.30$ ). Likewise, nearly half of the respondents 'strongly agree' that food prices would rise if farmers were unable to grow essential foodstuff $(M=4.28, S D=1.17)$. It is evident from this response that the public does not endorse policies that rely on imports, especially in essential food products. Instead, they wholeheartedly support farmers and domestic production.

The Covid-19, which imprisoned people in their homes, also led to crucial decisions being made in agricultural foreign trade. Closing borders, banning flights, uncertainties have increased the importance of meeting food needs from within the country. Following the outbreak, both domestic sales and exports increased. Increasing international demand has created the necessity to take measures for export in terms of supply-demand balance in domestic markets (Palabiyık, 2020). These measures are affecting both the delivery of food where it is needed and the producers negatively. Turkey, a country that is generally self-sufficient in fruits and vegetables, is dependent on imports, especially in cereals, forage crops and oil plants. For the last 5-6 
years, every product with high production cost (therefore, with high market price) within the country was imported to reduce food inflation.

The wheat produced by Turkey is only enough to meet its own needs. Turkey imported about 10 million tons of wheat in 2019 . About $80 \%$ of that is from Russia. Most of this import is used for the export of pasta, flour and other products. Turkey also imports bran, corn and other products from Russia. After the outbreak, however, Russia subjected wheat exports to a quota. Russia's decision increased the export price for wheat by $\$ 15-20$ per ton. Although this restriction does not cause shortages in the domestic market, the export of products such as pasta and flour will decrease. If import becomes burdensome, there may limit the production of flour and pasta from domestic wheat for export purposes. The Eurasian Economic Union also quota products such as soy, sunflower, corn. Turkey is negatively affected by this enforcement since it is an importer of cereals, pulses and oilseeds. Tax relief was brought about on sunflower and crude oil imports to prevent the prices from adversely affecting the domestic market until the harvest of new products. However, sellers in import countries raised prices around $\$ 100$ per tonne after the tax reduction was introduced, and the price is expected to rise further (Yildirim, 2020). Furthermore, the oil price increase, strict hygiene and quarantine measures taken (such as the obligation of truck drivers to wait for 14 days) induce financial hardship for truck, airline and aircraft exports (Istanbul Chamber of Commerce, 2020). Export decreases due to the decrease in the number of vehicles and flights and the increase in costs.

The survey results confirm that respondents are concerned about closing crossings between countries will make food imports $(M=4.06$, $S D=1.18)$ and exports $(M=4.17, S D=1.15)$ difficult. More than half of the participants replied 'strongly agree' to the statement 'closing customs crossings between countries will also hamper food imports - prevent food exports'. Despite the assurance of the food authorities, the panic caused by the outbreak, and the uncertainty of how long the outbreak would have caused nearly half of the participants to worry about the food shortage if the essential food products could not be imported $(M=3.36 S D=1.45)$. Turkey's agricultural exports have increased approximately 4.4 times in the last fifteen years, while its imports have increased 5.4 times (Yavuz and Dilek, 2019). Like other sectors, the agricultural sector depends on imports. High amounts of feed, seed, pesticide, fertiliser, and equipment are imported. The increase in the exchange rates increases the prices of these inputs; thus, the production cost of the farmer increases. The government has been trying to suppress these costs with policies based on imports in recent years. This leads $54.9 \%$ of respondents to worry that prices will rise if good imports are not made because of the outbreak (see Table 2).

People are worried that the coronavirus is transmitted through farm animals, as the first cases are reported to come from an animal market in China. The CDC (Centres for Disease Control and Prevention), Food and Drug Administration, Department of Agriculture (US), World Health Organization (WHO), BfR (The German Federal Institute for Risk Assessment) and ANSES (French Agency for Food, Environmental and Occupational Health and Safety) all announced that the virus is not transmitted through food. WHO said there was no evidence that Covid-19 being transmitted through food (WHO, 2020). ANES said there was no evidence that farm animals played a role in the spread of the virus (ANSES, 2020; Rettner, 2020). Current research suggests that the virus does not multiply on or in foods, unlike bacteria that cause foodborne illness and virus can survive on most surfaces for only a limited time. Therefore, even if a product or packaging carries the virus, it can die during transport (Wadyka, 2020).

Despite the statements of all the aforementioned authorities, the percentage of those who 'strongly agree' to the statement that the virus will affect livestock farmers was $47.2 \%$. Participants who 'strongly agree' on the statements that 'they were concerned about the virus contamination on imported food products from abroad' was $43.5 \%$, while the ratio of those who 'strongly agree' that 'virus will adversely affect the food export to be made from Turkey' was the highest of $47.7 \%$. The reason for these concerns is that 
Table 2 - Likert type statements for agriculture and food industry and evaluation of participants' responses.

\begin{tabular}{|c|c|c|c|c|c|c|c|c|c|}
\hline & \multicolumn{5}{|c|}{$\%$} & \multirow[t]{2}{*}{ Mean } & \multirow[t]{2}{*}{$S D$} & \multirow[t]{2}{*}{ Skew } & \multirow[t]{2}{*}{ Kurt } \\
\hline & 1 & 2 & 3 & 4 & 5 & & & & \\
\hline $\begin{array}{l}\text { These are the months of sowing and } \\
\text { planting in agriculture. If planting is not } \\
\text { done due to curfew, there may be a shortage } \\
\text { of food in the coming months. }\end{array}$ & 3.5 & 3.4 & 18.2 & 12.9 & 61.7 & 4.25 & 1.1 & -1.33 & 0.88 \\
\hline $\begin{array}{l}\text { It worries me that we won't be able to } \\
\text { produce (plant harvest process) the basic } \\
\text { foodstuffs we need. }\end{array}$ & 8.4 & 6.3 & 17.5 & 16.6 & 51.2 & 3.96 & 1.3 & -1.01 & -0.16 \\
\hline $\begin{array}{l}\text { Closing customs crossings between } \\
\text { countries will also hamper food imports. }\end{array}$ & 5.6 & 4.0 & 21.0 & 17.8 & 51.6 & 4.06 & 1.18 & -1.09 & 0.29 \\
\hline $\begin{array}{l}\text { Not being able to import the basic } \\
\text { foodstuffs we need could create a food } \\
\text { deficit within the country. }\end{array}$ & 16.6 & 10.5 & 25.7 & 14.5 & 32.7 & 3.36 & 1.45 & -0.33 & -1.19 \\
\hline $\begin{array}{l}\text { Food prices rise if we can't import the } \\
\text { essential foodstuffs we need. }\end{array}$ & 11.7 & 10.0 & 23.4 & 15.2 & 39.7 & 3.61 & 1.39 & -0.56 & -0.96 \\
\hline $\begin{array}{l}\text { Food prices rise if we can't grow the } \\
\text { essential foodstuffs we need. }\end{array}$ & 4.0 & 2.1 & 11.7 & 37.9 & 44.4 & 4.28 & 1.17 & .988 & -1.46 \\
\hline $\begin{array}{l}\text { Closing customs crossings between } \\
\text { countries will also prevent food exports. }\end{array}$ & 5.1 & 4.0 & 16.4 & 17.8 & 56.8 & 4.17 & 1.15 & -1.31 & 0.82 \\
\hline $\begin{array}{l}\text { The products we cannot export will remain } \\
\text { unsold, and farmers will suffer financial } \\
\text { loss. }\end{array}$ & 9.6 & 7.2 & 21.0 & 17.8 & 44.4 & 3.8 & 1.33 & -0.8 & -0.54 \\
\hline $\begin{array}{l}\text { The increase in corona cases in Turkey will } \\
\text { detract from Turkey's fruit and vegetable } \\
\text { exports. }\end{array}$ & 7.7 & 5.8 & 20.1 & 18.7 & 47.7 & 3.93 & 1.27 & -0.96 & -0.16 \\
\hline $\begin{array}{l}\text { Due to the pandemic constraints sowing } \\
\text { and planting in the fields cannot be done, } \\
\text { and the economic situation of the farmers } \\
\text { will get worse. }\end{array}$ & 2.3 & 3.5 & 12.4 & 46.5 & 35.3 & 4.09 & 0.91 & -1.22 & 1.82 \\
\hline $\begin{array}{l}\text { Corona outbreak can affect businesses that } \\
\text { raise livestock. }\end{array}$ & 6.5 & 7.9 & 22.0 & 16.4 & 47.2 & 3.9 & 1.26 & -0.83 & -0.42 \\
\hline $\begin{array}{l}\text { The economic aid package announced by } \\
\text { the government should include measures } \\
\text { for agriculture. }\end{array}$ & 1.4 & 3.5 & 10.0 & 41.1 & 43.9 & 4.23 & 0.87 & -1.29 & 1.89 \\
\hline $\begin{array}{l}\text { Working and shelter conditions of seasonal } \\
\text { agricultural workers are vulnerable to the } \\
\text { virus. }\end{array}$ & 1.9 & 2.6 & 15.7 & 12.9 & 67.1 & 4.41 & 0.97 & -1.56 & 1.72 \\
\hline
\end{tabular}

Notes: 1: strongly disagree, 2: disagree, 3: no opinion, 4: agree, 5: strongly agree.

although Turkey is an industrialising country, the agriculture and food sector still has a large share in exports.

\subsection{Agricultural sector and measures against Covid-19}

On May 4, the European Commission approved and issued the latest package to support the agriculture and food sectors exceedingly harmed by the coronavirus outbreak. In addition to other measures, the European Commission scheduled to grant the Member States to use farmers and small agri-food businesses from rural development funds of $€ 5,000$ per farmer and $€ 50,000$ per small business. In keeping with this Temporary Framework for state aid, farmers can utilise a maximum of $€ 100,000$ per farm, and food processing and marketing companies can use a maximum of $€ 800,000$ (European Com- 
mission, 2020). The Coronavirus Food Assistance Program (CFAP) in the US allocated \$9.6 billion for the livestock industry $(\$ 5,1$ billion for the livestock industry, $\$ 2.9$ billion for dairy, $\$ 1.6$ billion for hogs), $\$ 3.9$ billion for row-crop producers, and $\$ 2.1$ billion for speciality crop (fruit and vegetable) producers. Besides, there will be a $\$ 500$ million payment for other crops. These payments were capped at $\$ 125,000$ per commodity and a total of $\$ 250,000$ per individual or entity. The Program contains further a $\$ 3$ billion purchase of agricultural products to back producers and cater food for deprived people (USDA, 2020). Canada has announced to give $\$ 252$ million in aid to help offset the financial pressure the Covid-19 outbreak has created on the farm and food processing industry. But one of Canada's largest farm groups, the Canadian Federation of Agriculture (CFA), had requested $\$ 2.6$ billion in emergency funding (Potenteau, 2020). The UN's International Agricultural Development (IFAD) has provided us $\$ 40$ million aid to the farmers and rural communities. In addition to its offering, IFAD aims to collect a minimum of $\$ 200$ million from member states, foundations and the private sector (IFAD, 2020).

Turkey has announced two economic support packet, first one on March 18, 2020 (Budak and Karakas, 2020), and second on April 17, 2020 (Official Gazette, 2020). However, experts pointed out that there is no new support given or planned to be given to agriculture as part of coronavirus measures. In the economic measures announced, many sectors were included in the "force majeure" regulations and taxes and other debts were deferred. However, the agriculture and food sectors were kept exempt from this regulation. It was stated that the low-interest loan support reported to be given to farmers by Agricultural Bank and Agricultural Credit Cooperatives is not related to the coronavirus, since it is the support provided within the scope of the routine decision made every year (Yildirim, 2020).

Moreover, agricultural support payments lagged behind March 2019 as of the end of March 2020. In the first quarter of 2019, $\ 8.2$ billion of agrarian support of $\bigotimes 16.2$ billion was paid. While $₫ 2.4$ billion of $\bigotimes 22.1$ billion of sup- port that should be paid in 2020 will be paid by the end of May ( $\mathbb{Q}=$ Turkish Lira) (CNNTurk, 2020). Even in crisis conditions, it is stated that the aid paid to the farmer reached farmers accounts after all the relevant cuts have been made.

The survey results show that respondents are aware that the economic packages announced do not include measures to support farmers. Turkey has been facing economic difficulties before Covid-19 outbreak, and the emphasis was primarily on to support SMEs and the industry. Undoubtedly, supporting these institutions is vital for the survival of the economy. The crisis conditions revealed the problems that were known before but avoided because they were not that apparent so much in our daily lives, and the economic measures announced revealed the vulnerability of farmers and farming systems. Only $4.9 \%$ of the participants $(M=$ $4.23, S D=0.87$ ) did not find it necessary to add the agriculture sector within the measures taken by the government. This reveals the need for the government to reconsider its priorities in its decisions.

\section{Conclusions}

The health, food, agriculture and transport sectors are critical in the fight against the Covid-19 crisis and are struggling to maintain their limited economic activities. Countries are fighting the virus and are using every means available. Nevertheless, the agriculture sector is most affected by the outbreak, among other industries, due to its long-standing problems and distinctive characteristics.

In the supply side, the producers' concern about virus transmission, the inability of seasonal workers to arrive due to reduced travel of measures to prevent the spread of the virus, the difficulties in supplying raw materials impeding the production, in addition, the restriction of supply chains and the reduction of financing opportunities increase the costs. In the demand side, the increase in consumption seen in the first days due to panic purchases will decrease. The demand will further decrease due to rising uncertainty, rising food prices and living costs, and reduced ability to spend as a result of job losses. 
According to a calculation by FAO, one out of every 5 calories an individual takes passes across the border of at least one country. Closing borders, quarantines, and disruptions in the market and supply chains, trade restrictions can impede people's access to adequate/diverse and nutritious food sources, especially in countries hit hard by the virus or already affected by high levels of food insecurity.

Coronavirus outbreak has emerged the strategic importance of the agricultural sector and has created a social awareness. The Covid-19 lead countries to further push their self-sufficiency policies in food production. Indeed, food nationalism is rising since the outbreak. Experts warn that coronavirus-like outbreaks may occur in the future. Strategic plans for National Agricultural Development should be drawn up, especially in underdeveloped and developing countries. Instead of each country specialising in a single product or a narrow range of products in agriculture, it is necessary to return to production policies that cover a wide range of food varieties to meet the domestic food needs. It is of great importance to improve working and living conditions in the rural, so as not to be caught unprepared for such outbreaks in the future as it is now. In contemplation of ensuring food security, reduce dependency on foreign countries and avoid exposure to food terrorism by foreign states, attention should be paid to the protection of small family farming, which has an optimum enterprise size and uses agricultural resources more efficiently and provides better sustainability.

Social protection programs should be in place; incomes and purchasing power should be maintained, especially for the most affected households. Food prices must be suppressed. Active measures need to be taken to reduce food waste and losses, provide subsidies to food producers, and reduce import tariffs. Trade restrictions (limiting trade and mobility of goods) should be avoided, food, feed and input supply should be protected. Furthermore, the government should temporarily reduce VAT and other taxes, review the tax policy on imported goods, and consider the potential effects of currency devaluation to compensate for potential cost increases. Governments, industries and funds should increase the amount of aid to farmers, seasonal workers, pro- ducers and vendors facing export bans, which are most affected by Covid-19 and oversee the effectiveness of those aids.

\section{References}

ANSES, 2020. COVID-19 cannot be transmitted by either farm animals or domestic animals. https:// www.anses.fr/en/content/covid-19-cannot-betransmitted-either-farm-animals-or-domestic-animals-0. Accessed May 7, 2020.

Aslanhan U., 2020. Turkey has at least 6 months'stock in food and drink. AA.com. https://www.aa.com.tr/ tr/ekonomi/turkiyenin-gida-ve-icecekte-en-az-6aylik-stoku-var/1806847. Accessed April 21, 2020.

Bal G., 2020. Agriculture was caught ' 65 years old' ... Gendarmerie did not permit farmers to work. Cumhuriyet. http://www.cumhuriyet.com.tr/haber/tarim65-yasa-takildi-jandarma-ciftcilere-calisma-izni-vermedi-1730385. Accessed April 20, 2020.

Batuk M.N., 2020. The excess of farmers over 65 years of age hinders production. Dunya. https:// www.dunya.com/sektorler/tarim/65-yas-ustu-ciftcilerin-fazlaligi-uretimi-aksatiyor-haberi-466685. Accessed April 15, 2020.

Budak C.M., Karakas I., 2020. President Erdogan unveils economic stability package. AA.com. https:// www.aa.com.tr/tr/koronavirus/cumhurbaskani-erdogan-ekonomik-istikrar-kalkani-paketini-acikladi/1770929. Accessed April 21, 2020.

Calkaya M., 2020. Domestic seed use will increase with the effect of Covid-19. AA.com. https://www. aa.com.tr/tr/ekonomi/kovid-19un-etkisiyle-yerli-ve-milli-tohum-kullanimi-artacak/1803987. Accessed April 21, 2020.

CNNTurk, 2020. The minister announced: 1 billion 626 million pounds of support payments start today. https://www.cnnturk.com/ekonomi/son-dakikabakan-duyurdu-1-milyar-626-milyon-liralikdestek-odemeleri-bugun-basliyor. Accessed May 8, 2020.

EuroNews, 2020. Coronavirus (Covid-19): What is the mortality rate by country? https://tr.euronews. com/2020/04/22/koronavirus-covid-19-ulkeleregore-olum-oran-kac. Accessed May 6, 2020.

European Commission, 2020. Jobs and economy during the coronavirus pandemic. https://ec.europa.eu/info/live-work-travel-eu/health/coronavirus-response/jobs-and-economy-during-coronavirus-pandemic_en. Accessed May 7, 2020.

George D., Mallery M., 2010. SPSS for Windows Step by Step: A Simple Guide and Reference,17.0 update (10a ed.) Boston: Allyn \& Bacon. 
IFAD (International Fund for Agricultural Development), 2020. New IFAD fund launched to help prevent rural food crisis in the wake of Covid-19. https://www.ifad.org/en/web/latest/news-detail/asset/41877895. Accessed May 7, 2020.

Is1k E., 2020. We need to see agriculture as a strategic area. AA.com. https://www.aa.com.tr/tr/politika/ iyi-parti-genel-baskani-aksener-tarimi-stratejikbir-alan-olarak-gormemiz-gerek/1808432. Accessed April 20, 2020.

Istanbul Chamber of Commerce, 2020. About the decisions made in international transportation due to the coronavirus outbreak. https://www.ito.org. $\mathrm{tr} / \mathrm{tr} /$ duyurular/detay/koronavirus-salgini-sebebiyle-uluslararasi-tasimacilikta-alinan-kararlar-hk. Accessed May 10, 2020.

Official Gazette, 2020. The Law on reducing the effect of the new coronavirus (Covid-19) outbreak on economic and social life and the law on amending some laws. Law No. 7244, Date of Admission: 16 April 2020, No: 31102. Official Gazette. https://www.resmigazete.gov.tr/eskiler/2020/04/20200417-2.htm. Accessed May 10, 2020.

Ozdemir O., 2020. Does the coronavirus outbreak pose a risk to the food and agriculture sector in Turkey? BBC News Turkish. https://www.bbc. com/turkce/haberler-turkiye-52175470. Accessed April 20, 2020.

Ozkok C.K., 2020. Minister of Agriculture and Forestry Pakdemirli: those engaged in agriculture and livestock activities will be exempt from the curfew. AA.com. https://www.aa.com.tr/tr/turkiye/ tarim-ve-orman-bakani-pakdemirli-tarim-ve-hayvancilik-faaliyetlerinde-bulunanlar-sokaga-cikma-yasagindan-muaf-tutulacak/1806441. Accessed April 20, 2020.

Palabıy1k D.C., 2020. Emergency action plan for legumes products. AA.com. https://www.aa.com. $\mathrm{tr} / \mathrm{tr} /$ turkiye/bakliyat-urunleri-icin-acil-eylem-plani/1810441. Accessed April 21, 2020.

Potenteau D., 2020. Coronavirus: BC Fruit Growers Association calls federal aid 'profoundly underwhelming'. Global News. https:/globalnews.ca/ news/6908433/coronavirus-b-c-fruit-growers-federal-assistance/. Accessed May 7, 2020.

Rettner R., 2020. Can you catch COVID-19 from food? Live Science. https://www.livescience.com/ coronavirus-food-risk.html. Accessed May 7, 2020.

Schrotenboer B., 2020. US agriculture: Can it handle coronavirus, labor shortages and panic buying? USA Today. https://www.usatoday.com/story/ money/business/2020/04/04/coronavirus-tests-a- mericas-food-supply-agriculture/5096382002/. Accessed April 22, 2020.

Tan H., 2020. A food crisis looms as coronavirus forces farms to stay idle and countries hoard supplies. CNBC. https://www.cnbc.com/2020/03/30/ coronavirus-food-crisis-looms-as-farms-idle-countries-hoard-supplies.html. Accessed April 23, 2020.

Turkstat, 2019. Address based population registration system results. Turkish Statistical Institute. http:// www.tuik.gov.tr/PreTabloArama.do?metod=search\&araType=vt. Accessed April 26, 2020.

USDA(US Department of Agriculture), 2020. USDAAnnounces coronavirus food assistance program. https:// www.usda.gov/media/press-releases/2020/04/17/usda-announces-coronavirus-food-assistance-program. Accessed May 7, 2020.

Wadyka S., 2020. Answers to common questions about coronavirus and the food you eat. Consumer Reports. https://www.consumerreports.org/food-safety/coronavirus-common-questions-about-the-foodyou-eat-food-safety/. Accessed May 7, 2020.

WHO (World Health Organisation), 2020. Coronavirus disease 2019 (COVID-19). Situation Report - 32. https://www.who.int/docs/default-source/coronaviruse/situation-reports/20200221-sitrep-32-covid-19. pdf?sfvrsn=4802d089_2. Accessed May 7, 2020.

Yavuz F., Dilek S., 2019. Overview of Turkish Agriculture. Istanbul: SETA.

Yildirim A.E., 2020. Agricultural export bans on corona days. Dünya. https://www.dunya.com/kose-yazisi/ korona-gunlerinde-tarim-ihracati-yasaklari/466357. Accessed April 20, 2020.

Yildizalp Ozmen M., 2020a. A tea farming board should be set up immediately. AA.com. https:/www.aa.com. $\mathrm{tr} / \mathrm{tr} /$ politika/chpli-saribal-derhal-bir-cay-tarim-kurulu-kurulmali/1806182. Accessed April 20, 2020.

Yildizalp Ozmen M., 2020b. The state should pay farmers' insurance premiums. AA.com. https:// www.aa.com.tr/tr/politika/chp-genel-baskanyardimcisi-saribal-ciftcinin-sigorta-primleri-devlet-tarafindan-odensin/1807394. Accessed April 20, 2020.

Yildizoglu E., 2020. Coronavirus outbreak: Will there be a food crisis as a following economic depression? BBC News Turkish. https:/www.bbc.com/ turkce/haberler-dunya-52319796. Accessed April 20, 2020.

Yuruk B., 2020. UN Food and Agriculture Organization: Covid-19 may affect the food system. AA.com. https:// www.aa.com.tr/tr/dunya/bm-gida-ve-tarim-orgutu-kovid-19-gida-sistemini-etkileyebilir/1808425. Accessed April 21, 2020. 
